\title{
ICHTHYOFAUNAL DIVERSITY OF RIVER PRAVARA NEAR PRAVARA SANGAM (NEWASA). DISTRICT AHMEDNAGAR (M.S.)
}

\author{
Tapase S.D. and Patole S. A.
}

Dept. of Zoology, Shri. Dnyaneshwar Mahavidyalaya Newasa - 413603*

\author{
Communicated : 17.02 .20
}

\begin{abstract}
River Pravara is one of the tributaries of river Godavari. Fishes were collected during the year June, 2018 to May 2019. For the study of Ichthyofaunal diversity of river Pravara near Pravarasangam (Newasa) District Ahmednagar (M.S.). The survey was made from five collection centre of Pravarasangam (Newasa). The present study of the total no of 31 species belonging to 15 genera, 5 order's and 11 families of fishes. Cypriniformes order is dominant with 10 species followed by perciformes and Siluriformes. The result shows rich fish diversity. The Pravara river is source of capturing the fishes in this region.It has the economic source to the fisherman.
\end{abstract}

Key words: Ichthyofaunal Diversity, River Pravara

\section{INTRODUCTION:}

The fishes are the most important group of vertebrates. Millions of human being is suffer from hunger and mall nutrition. Fish fauna are the rich source of food. Fishes provided several products and byproduct. The fish provides fish oil used in medicinal and industrial uses. Fishes diet provided rich source of protein, carbohydrate and trace of several vitamin A, D and vitamin B- complex. The fishes show edible and economic value.

Fishes of the fresh or inland water bodies of the Indian sub-continents have been a subject of study since last century; Hamilton; Buchanan (1922); Tiwari Jaryram (1981); Talwar and Jhingran (1991);

Reservoirs fishery in India is also important from social economic point of view assist as the potential providing employment to about millions people. According to Sughnan (1995); total area under the reservoirs in India is 3.1 million hectors; there are includes 19000 small reservoirs with a total water surface area 14855. 57 hectors and about 180 medium and
56 large reservoirs of 527641 and 1140268 hector respectively.

In the area of Maharashtra 179430 hectors under reservoirs. More than 516 tones of fishes of these areas in Maharashtra.

The diversity of fish from these reservoirs as well as from rivers of this district; which is useful to get information on diversity of fishes. Such a work at latter provide the required database for further fishery culture development. It also and also beneficial to fishermen for catches the economical important fishes from river like Pravara rivers of district Ahmednagar. Present investigation was undertaken to study the status of Ichthyofaunal diversity of river Pravara near Pravara sangam (Newasa). District Ahmednagar The river Pravara is one of the tributary of river Godawari. The pravara sangam is spread between $19037^{\prime} \mathrm{N}$ latitude, 750 1' E longitude.

\section{MATERIAL AND METHOD:}

The fishes were collected from the different fishing stations with the help of local fisherman from river pravara. They were also 
collected from the market of pravara sangam, Kaygaon, Newasa, and Newasa phata were they are collected from river pravara. The examination of colour pattern and morphology, they were cleaned with clean and warm water to remove dirt, microorganism and blood strains. Standard identification keys were used for identification of specimen up to species level by Hamilton Buchanan (1922), Day (1958 1967 and 1978), Jhingram (1982), Talwar and Jhingran (1991)

\section{RESULT AND DISCUSSION:}

The present work confirms the occurrence of thirty one species belongs to five orders and fifteen genera and eleven families of fishes. The order cypriniformes was dominant with seventeen fish species to be followed the order silluriformes five species and channiformes with three species, order perciformes with species five species and clupeiformes with one species. The work is supported by number of earlier studied on similar lines. Das and Nath (1971) revised the fish fauna of Jammu and enlisted the presence of 27 fish species belong to eight families and fifteen genera in river Tawi and its tributaries. Dutta et al (2003) in a survey of river Tawi and its varies tributaries have reported the occurance of ninety six fish species belong to seven orders, twenty families and fifty two genera. Pawar et al (2003) studied fish diversity in the sirur dam and confermed the occurrence of eleven fish species belong to five orders. Kamble et.al. (2006) recorded 27 species belonging 18 genera, 7 order and 11 families from Manjara River, near Kallam district Osmanabad. Pawar et.al (2007) were recorded 26 fish species from Pethwadas dam Taluka Kandhar in Nanded District, Maharashtra, India. Rathod et.al. (2008) were investigated 12 fish species from 12 different genera belonging to 3 orders of families from class teleost from Umra (Shamsudin) reservoir, Washim District
Maharashtra. Anish Dua and Chander Prakash (2009) were recorded 61 species of fishes from Harike wetland and these belonging to 17 families, and 35 genera.

Patole (2014) were recorded 83 species of belong to six order, eleven families, 24 genus and 32 species were Cypriniformes order is dominat with 19 speceis in Nandurbar district, Maharashtra India. Nikam D. S.et al (2014) identified 23 species of fishes belong into 21 genera, 12 families and 5 orders from Asti lake Tal Mohol, district Solapur

Diya Kumudini and Agrawal (2015) were recorded 39 fish species belong five ordr 20 genera and eleven families from Dandia pond and 42 fish species belong to Five orders, 22 genera and eleven families from Mahurband pond in Kanker city of north Baster Kanaker district.C.G. India.

\section{REFERENCES:}

Anish Dua and Chander Parkash (2009). Distribution and abundance of fish populations in Harike wet land - Ramsar site in India. J. Environ. Biol. 30(2): 247-251.

Das, S.M. and Nath S. (1971). A revision of the fishes from Jammu provinces Kashmir. Science7;1-12

Day, F.S.(1978).The fishes of India. William and Sons Ltd. London.

Day, F. (1958). The fishes of India being a natural history of the fishes known to inhabit the seas and freshwater of India, Burma and Ceolon. Text \& Atlas 198 pts. London wiliam Dawson \& Sons. Ltd. 198.

Day Francis (1967). The Fishes of India, Vol.I and II,Jagamander Agency, New Delhi.

Dutta S.P.S., Kour H. and N. Zutshi (2003) : Ichthyofauna of river Tawi nad its tributariesof the rver Chimba, Jammu 
and Kashmir state. J. aqua. Boil.Volume 18 (2) 61-68.

Hamilton, Buchanan (1922) : An account of the fishes found in the river Gamga and its branches. Edinburg and London., VII - 405 pp. 39 pic.

Jhingran, V.G. (1982). Fish and fisheries of India. Hindustan Publishing Corporation New Delhi pp.268-269.

Kamble S.M., Mohekar A.D. and Bhagwan H.K. (2006). Biodiversity of fishes of river Manjara, near Kallam District Osmanabad J. Aqua.Biol. 21(3): 3-6.

Kumudini Diya and Agrawal R. K. (2015): The study of Icthyofaunal diversity in Dandia pond and Mahurband pond in Kanker city of north Bastar Kanker district, C. G. India. J. IOSR J. of Environmental science and food technology and toxicology.Vol. 1.(34-38)

Nikam. D. S., Shaikh A. L., Salunke P.S. and Rao K. R. ( 2014): Ictyofaunal diversity of Ashti Lake Tal Mohol, District Solapur. J Global J. for research analysis.Vol. 3 (15)

Patole S. S. (2014) : Ictyofaunal diversity of Nandurbar district, Maharashtra
India.J. Int. J. of Fisheries and aquatic studies.(167-172)

Pawar, S.K., A.M.Mane and Pulle, J.S. (2007). The fish fauna of Pethwadaj dam taluka Kandhar in Nanded Dist. Maharashtra, India J. Aqua. Biol. Vol.22 (2) : 55-58

Pawar S.K. , V.R. Madlapure and J.S. Pulle (2003) : The study on the fish diversity in the Shirur Dam near Mukhed, Nanded District. (MS) India J. aqua. Boil. Volume - 18 (2). 69-70.

Rathod, S. D., Malu, R. A., Dabhade, D. S., Patil, P. S., Charjan, A. P. and H.V. Wanjari (2008). Diversity of fish fauna of Umra (Shamsudin) reservoir Washim district, Maharashtra. J. Aqua. Biol. Vol. 23(1) : 17-20.

Sughnan V.V. (1995): Reservoir fisheries of India FAO Tech. Paper No. 345 FAO Rome 1- 425

Talwar P.K. Jhingaran A. (1991): Inland fishes of India and adjacent countriesOxford- IBH Publ.1 Shing, Co. Pvt. Ltd. New Delhi. Volume I and II : 115-116. 
Table 1. A Checklist of Fishes of River Pravara

\begin{tabular}{|c|c|c|c|c|c|}
\hline \multicolumn{3}{|c|}{ Order Cypriniformes } & \multicolumn{3}{|c|}{ Order Siluriformes } \\
\hline Family & Genus & Species & Family & Genus & Species \\
\hline \multirow{14}{*}{ Cyprinidae } & - Catala & catala & \multirow{3}{*}{ Bagridae } & \multirow{3}{*}{ Mystus } & seenghala \\
\hline & Rasbora & daniconius & & & vittatus \\
\hline & \multirow{3}{*}{ Labeo } & rohita & & & cavasius \\
\hline & & bata & Situridae & Wallago & attu \\
\hline & & calbasu & Claridae & Clarias & batrachus \\
\hline & \multirow{2}{*}{ Cirrihina } & mirigala & \multicolumn{3}{|c|}{ Order Clupeiformes } \\
\hline & & reba & Family & Genus & Species \\
\hline & \multirow{7}{*}{ Punctius } & sarana & Notopteridae & Notopterus & chitala \\
\hline & & ticto & Orde & Channifor & \\
\hline & & punctatus & Family & Genus & Species \\
\hline & & sophor & \multirow{3}{*}{ Channidae } & \multirow{3}{*}{ Channa } & gachua \\
\hline & & chola & & & muraliuss \\
\hline & & amphibious & & & straiatus \\
\hline & & conchonius & & & \\
\hline Balitoridae & Nemacheilus & botia & & & \\
\hline \multirow{2}{*}{ Cobitidae } & \multirow{2}{*}{ Lepidocehalichthys } & tharmalis & & & \\
\hline & & guntea & & & \\
\hline \multicolumn{3}{|c|}{ Order perciformes } & & & \\
\hline Family & Genus & Species & & & \\
\hline Gobidae & Glassogobius & giuris & & & \\
\hline \multirow{2}{*}{ Centropomidae } & \multirow{2}{*}{ Chanda } & ranga & & & \\
\hline & & nama & & & \\
\hline \multirow{2}{*}{ Anabantidae } & \multirow{2}{*}{ Anabus } & testudinus & & & \\
\hline & & cobojius & & & \\
\hline
\end{tabular}

